\title{
The comparison of colchicine and standard treatment in COVID-19 patients: A mini review
}

\author{
Yasmeen*, Dwi Aris Agung Nugrahaningsih, Woro Rukmi Pratiwi \\ Department of Pharmacology and Therapy, Faculty of Medicine, Public Health, and Nursing, \\ Universitas Gadjah Mada, Yogyakarta, Indonesia \\ https://doi.org/10.22146/ijpther.2381
}

Submitted: 20/08/2021

Accepted : 17/12/2021

Keywords:

colchicine

COVID-19

standard therapy

placebo

clinical evidence

\begin{abstract}
Coronavirus disease 2019 (COVID-19) was declared a pandemic in March 2020. There are several drugs used at different stages of the disease, but none seem to be completely effective. In the absence of any known therapy, many drugs have been tested, including colchicine. Colchicine differs from these other therapies in having pleiotropic mechanism of action, being less potent on any single target, and being an oral agent. It is also a better option since colchicine is not immunosuppressive, is not known to increase risk of infection, and is inexpensive. The aim of this study was to provide evidence of the role of colchicine in improving clinical outcome and reducing death rate of COVID-19 patients through literature mini-review. A mini-review, composed of previous RCTs comparing the use of colchicine in COVID-19 with standard care or placebo under the keyword "COVID-19", "COVID”, "coronavirus", "SARS-CoV-2", "coronavirus disease", "Colchicine", "CAS 64-86-8", "standard treatment", "standard care", "standard of care", "common treatment", "placebo", "clinical improvement", and "clinical response". The addition of colchicine to standard treatment can be beneficial in treating COVID-19. Studies included showed that colchicine has significantly improved time to clinical deterioration compared to the control group. Colchicine reduced the length of hospitalization and the need for supplemental oxygen therapy. One of the included studies mentioned that in outpatient settings, colchicine can prevent hospitalization and even death. Colchicine can improve the clinical outcome on CRP levels, the number of patients that need mechanical ventilation, and death rate in COVID-19 patients. The addition of colchicine to standard treatment should be considered to prevent clinical deterioration and death. Colchicine reduces the number of adverse effects in COVID-19 patients except for gastrointestinal adverse effects, especially diarrhea, which is consistently more common in the colchicine groups.
\end{abstract}

\begin{abstract}
ABSTRAK
Coronavirus disease 2019 (COVID-19) dinyatakan sebagai pandemi pada Maret 2020. Saat ini, beberapa obat digunakan pada berbagai kondisi penyakit, tetapi tidak ada yang sepenuhnya efektif. Dengan belum adanya terapi efektif, banyak obat yang diuji, termasuk kolkisin. Berdasarkan sifat anti-inflamasi kolkisin, para peneliti mengusulkan penggunaannya dalam mengobati COVID-19. Berbagai terapi telah diuji coba untuk COVID-19 dengan beberapa jalur yang sama seperti kolkisin. Kolkisin berbeda dari terapi lain dalam mekanisme kerja pleiotropicnya, kurang efek pada pemberian tunggal, dan dapat diberikan secara oral. Kolkisin juga pilihan yang lebih baik karena tidak bersifat imunosupresif, tidak meningkatkan risiko infeksi, dan tidak mahal. Penelitian ini bertujuan untuk membuktikan peran kolkisin dalam meningkatkan luaran klinis dan menurunkan angka kematian pasien COVID-19 melalui kajian singkat yang terdiri dari RCT sebelumnya yang membandingkan penggunaan kolkisin pada pasien COVID-19 dengan pengobatan standar atau plasebo dengan kata kunci "COVID-19", “COVID”, "coronavirus", "SARS-CoV-2", "penyakit coronavirus", "kolkisin”, “CAS 64-86-8”, "pengobatan standar”, "perawatan standar”, "standar perawatan", "pengobatan umum”, "plasebo", dan "peningkatan klinis”.
\end{abstract}




\begin{abstract}
Penambahan kolkisin pada pengobatan standar bermanfaat dalam mengobati COVID-19. Penelitian menunjukkan bahwa kolkisin telah secara signifikan meningkatkan waktu untuk mencapai perparahan penyakit dibandingkan dengan kelompok yang tidak menerima kolkisin. Pada pemberian awal perjalanan penyakit, kolkisin mengurangi lama rawat inap dan kebutuhkan terapi oksigen tambahan. Salah satu penelitian pada pasien yang dirawat di komunitas, COLCORONA, menyebutkan bahwa pada pasien rawat jalan, kolkisin dapat mencegah rawat inap dan bahkan kematian. Kolkisin merupakan obat yang dapat meningkatkan luaran klinis berupa penurunan kadar CRP, jumlah pasien yang membutuhkan ventilasi mekanik, dan angka kematian pada pasien COVID-19. Penambahan kolkisin untuk pengobatan standar perlu dipertimbangkan untuk membantu mencegah kerusakan klinis dan kematian. Kolkisin mengurangi kejadian efek samping pada pasien COVID-19 kecuali diare, yang secara konsisten lebih banyak terjadi pada kelompok kolkisin.
\end{abstract}

\section{INTRODUCTION}

Coronavirus disease 2019 (COVID-19) was declared a pandemic disease in March 2020, more than 50 countries have been infected with this virus, which has been classified as highly contagious but not as lethal as severe acute respiratory syndrome coronavirus (SARS-CoV) and Middle East respiratory syndrome coronavirus (MERS-CoV). ${ }^{1}$ It has been a challenge to find an effective drug to control and treat the COVID-19 infection. Currently, there are several drugs used at different stages of the disease, but none of them have proven to be completely effective. In the absence of any known effective therapy, many drugs have recently been tested, including colchicine.

Colchicine is a medication that has been used to prevent and treat gout attacks and some other autoinflammatory syndromes such as Adult-onset Still's disease, Behcet's disease or familial Mediterranean Fever as well cardiac conditions. It decreases the symptoms of patients associated with inflammatory response, and some clinical manifestations such as arthralgia, headache, and pulmonary infiltrates. $^{2}$ The goal is therefore to systematically review literatures and to provide evidence of the therapeutic role of colchicine in patients diagnosed with COVID-19.

\section{METHODS}

\section{Protocol of study}

In this study, a protocol based on the transparent reporting of systematic reviews and meta-analysis (PRISMA) was used (FIGURE 1). The protocol has been approved by the Health and Medical Research Ethics Committee, the Faculty of Medicine, Public Health and Nursing, Universitas Gadjah Mada, Yogyakarta (ref. no. KE/FK/0727/EC/2021).

\section{Criteria of study}

The articles evaluating the effect of colchicine on clinical outcome, study population from RT-PCR confirmed COVID-19 patients, written in English, and full text article available that published from January 2020 until January 2021 were included in this study. Whereas, the review articles, preclinical study articles, non RCTs articles were excluded.

\section{Information sources and search strategy}

Three systematic searches were performed using Medline/PubMed, Scopus, and Web of Science. The search was conducted based on the following keywords i.e. "COVID-19", "COVID”, "coronavirus", "SARS-CoV-2", "coronavirus disease", "Colchicine", 
"CAS 64-86-8”, "standard treatment”, "standard care", "standard of care", "common treatment”, "placebo", "clinical improvement", and "clinical response". The screening was conducted by reading the title, abstract, and full text of the articles based on the inclusion and exclusion criteria.

\section{Variable of study and operational definition}

Colchicine is an oral medicine to treat inflammation and pain. It has been successfully used for the treatment and prevention of gout. Colchicine was repurposed to treat inflammation due to COVID-19 during pandemic. In this study, colchicine was considered as independent variable. As dependent variable was clinical outcome and death rate. The clinical outcome was the changes in CRP levels and the need of mechanical ventilation, whereas the death rate was the ratio between deaths and individuals in a specific population and time frame.

\section{Assessment of risk of bias}

Version 2 of the Cochrane risk-ofbias tool for randomized trials (RoB 2) was used to assess the risk of bias in RCTs included in this study.

\section{RESULTS}

Based on the searching process conducted on eligible publications, a total of 35 articles were collected. However, only 3 articles fulfilled the inclusion and exclusion criteria. Another articles were excluded because they were unpublished results, not randomized trial, review articles, and preclinical studies (FIGURE 1 ). For the 3 articles included in this study, RoB-2 tool was applied to assess the risk of bias and the result showed that all of the articles have a low risk of bias as shown on TABLE 1 .

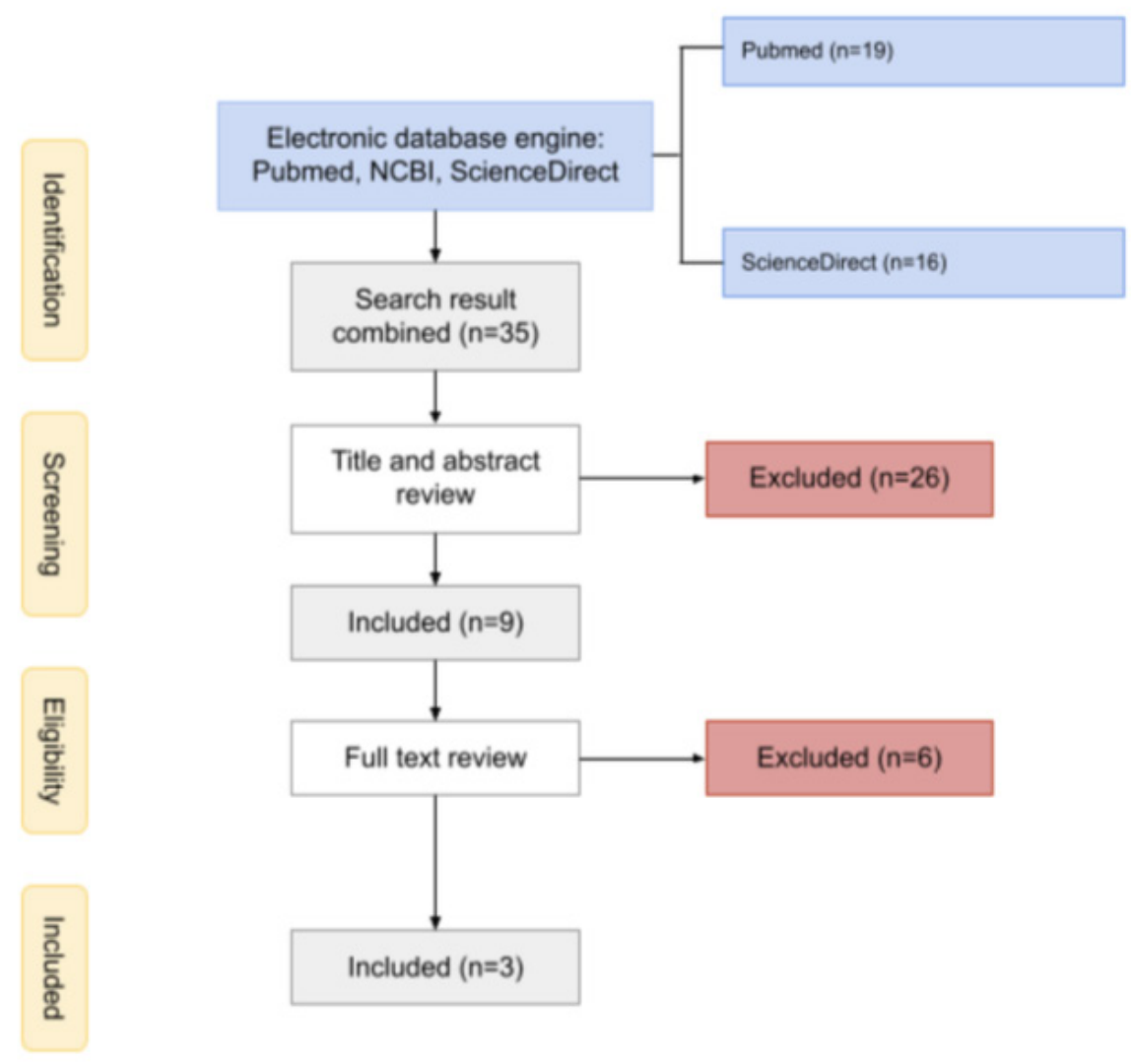

FIGURE 1. Article selection using PRISMA flow diagram 
TABLE 1. Risk of bias assessment for clinical trials using Cochrane risk of bias 2 (RoB 2) tool

\begin{tabular}{|c|c|c|c|c|c|c|}
\hline Study & $\begin{array}{l}\text { Random } \\
\text { sequence } \\
\text { generation }\end{array}$ & $\begin{array}{l}\text { Allocation } \\
\text { Concealment }\end{array}$ & $\begin{array}{l}\text { Blinding of } \\
\text { participants } \\
\text { and personnel }\end{array}$ & $\begin{array}{l}\text { Blinding to } \\
\text { outcome } \\
\text { assessment }\end{array}$ & $\begin{array}{l}\text { Incomplete } \\
\text { to outcome } \\
\text { data }\end{array}$ & $\begin{array}{l}\text { Selective } \\
\text { reporting }\end{array}$ \\
\hline Tardif et $a .^{3}$ & + & + & + & + & + & + \\
\hline Lopez et al. ${ }^{4}$ & + & + & + & + & + & + \\
\hline Deftereos et al. ${ }^{5}$ & + & + & + & + & + & + \\
\hline
\end{tabular}

The 3 articles review in this study were conducted in different countries, different time, and different patient condition. Study by Tardif et al. ${ }^{3}$ was conducted in community setting, which means the patients involved had mild COVID-19. Study by Lopez et al. ${ }^{4}$ and Deftereos et al. ${ }^{5}$ were both conducted in hospital setting, hence the patients who participated in the studies had moderate to severe COVID-19.

Standard treatment given in each study also varied, but some were similar. The difference of standard treatment given in each study must be taken into consideration while interpreting the results. Further details on study characteristics can be found in TABLE 2 .

TABLE 2. Study characteristics

\begin{tabular}{|c|c|c|c|c|}
\hline Study & $\begin{array}{c}\text { Study } \\
\text { Population }\end{array}$ & Colchicine Dose & $\begin{array}{l}\text { Colchicine vs. } \\
\text { Control Group }\end{array}$ & Standard Treatment \\
\hline Tardif et al. ${ }^{3}$ & $\begin{array}{l}\text { Non-hopital- } \\
\text { ized patients } \\
\text { older than } 40 \\
\text { years }\end{array}$ & $\begin{array}{l}0.5 \mathrm{mg} \text { twice daily } \\
\text { for } 3 \text { days, then once } \\
\text { daily for } 27 \text { days }\end{array}$ & $\begin{array}{l}2235(49.7 \%) \text { vs. } \\
2253(50.3 \%)\end{array}$ & $\begin{array}{l}\text { Hydroxychloroquine, } \\
\text { oral anticoagulant, } \\
\text { aspirin, other platelet } \\
\text { agents }\end{array}$ \\
\hline Lopez et al. ${ }^{4}$ & $\begin{array}{l}\text { Hospitalized } \\
\text { patients older } \\
\text { than } 18 \text { years }\end{array}$ & $\begin{array}{l}0.5 \mathrm{mg} \text { thrice daily for } \\
5 \text { days, then } 0.5 \mathrm{mg} \\
\text { twice daily for } 5 \text { days }\end{array}$ & $\begin{array}{l}36(50 \%) \text { vs. } \\
36(50 \%)\end{array}$ & $\begin{array}{l}\text { Azithromycin, } \\
\text { hydroxychloroquine, } \\
\text { unfractioned heparin, } \\
\text { methylprednisolone, } \\
\text { supportive treatment }\end{array}$ \\
\hline Deftereos et al. ${ }^{5}$ & $\begin{array}{l}\text { Hospitalized } \\
\text { patients }\end{array}$ & $\begin{array}{l}1.5 \mathrm{mg} \text { loading dose } \\
\text { followed by } 0.5 \mathrm{mg} \\
\text { after } 60 \mathrm{~min} \text { and } \\
\text { maintenance dose of } \\
0.5 \mathrm{mg} \text { twice daily for } \\
21 \text { days }\end{array}$ & $\begin{array}{l}50(47.6 \%) \mathrm{vs} . \\
55(52.4 \%)\end{array}$ & $\begin{array}{l}\text { Hydroxychloroquine, } \\
\text { azithromycin, lopinavir/ } \\
\text { ritonavir, tocilizumab, } \\
\text { and supportive } \\
\text { treatment }\end{array}$ \\
\hline
\end{tabular}

In this study, we were looking at the results in 3 different indicators i.e. CRP levels, the number of patients that needed mechanical ventilation, and death (TABLE 3). In the study by Tardif et $a .^{3}$ the number of death occurred in $5(0.2 \%)$ out of 2235 patients in the colchicine group compared to $9(0.4 \%)$ out of 2253 in the control group. The CRP levels could not be collected due to the study being conducted in community setting. The number of patients that 178 needed mechanical ventilation was $11(0.5 \%)$ out of 2235 patients in the colchicine group compared to $21(0.9 \%)$ out of 2253 patients in the control group.

In the study by Lopez et al. ${ }^{4}$ none of the patients died in the colchicine group compared to $2(6 \%)$ out of 36 patients in the control group. CRP levels were evaluated in this study. Both groups started at similar levels of serum CRP. It was observed that CRP levels became different between the 2 groups in 
between days 2 and 4, with values near normal range (median $=1.3 \mathrm{mg} / \mathrm{dL}$ ) in the colchicine group at day 4 . In the control group, observed difference occurred at day 7 ( $<<0.001)$, but no return to normal range of median CRP was observed at that time. None of the patients included in the study needed mechanical ventilation.

In the study by Deftereos et al. ${ }^{5}$ the number of death occurred in $1(1.8 \%)$ out of 55 patients compared to $4(8 \%)$ out of 50 patients. At the start of the study, 72 (68.6\%) patients already had CRP values higher than at baseline (35 [70.0\%] in the control group and 37 [67.3\%] in the colchicine group; $p=0.76$ ), which does not allow for any meaningful comparison between the 2 groups in terms of this variable. In terms of the use of mechanical ventilation, $1(1.8 \%)$ out of 55 patients needed it in the colchicine group compared to 6 (12\%) out of 50 patients in the control group.

TABLE 3. Results (clinical outcome and death)

\begin{tabular}{|c|c|c|c|c|c|c|}
\hline \multirow[b]{2}{*}{ Result } & \multicolumn{2}{|c|}{ Tardif et al. ${ }^{3}$} & \multicolumn{2}{|c|}{ Lopez et al. ${ }^{4}$} & \multicolumn{2}{|c|}{ Deftereos et al. ${ }^{5}$} \\
\hline & $\begin{array}{c}\text { Colchicine } \\
n=2235\end{array}$ & $\begin{array}{l}\text { Control } \\
n=2253\end{array}$ & $\begin{array}{l}\text { Colchicine } \\
n=36\end{array}$ & $\begin{array}{c}\text { Control } \\
n=36\end{array}$ & $\begin{array}{l}\text { Colchicine } \\
n=55\end{array}$ & Control $n=50$ \\
\hline Death & $5(0.2 \%)$ & $9(0.4 \%)$ & $0(0 \%)$ & $2(6 \%)$ & $1(1.8 \%)$ & $4(8 \%)$ \\
\hline \multirow{3}{*}{$\begin{array}{l}\text { Creative protein } \\
\text { level [mg/dL, } \\
\text { median (IQR)] }\end{array}$} & & & $\begin{array}{c}\text { Day } 2: 4.3 \\
(2.1-6.4)\end{array}$ & $\begin{array}{l}\text { Day 2: } 8.4 \\
(3.7-12.8)\end{array}$ & \multirow{3}{*}{$3.1(0.8-9.8)$} & \multirow{3}{*}{$4.5(1.4-8.9)$} \\
\hline & - & - & $\begin{array}{c}\text { Day 4: } 1.3 \\
(0.4-3.2)\end{array}$ & $\begin{array}{c}\text { Day 4: } 4.3 \\
(1.7-9.0)\end{array}$ & & \\
\hline & & & $\begin{array}{c}\text { Day 7: } 0.5 \\
(0.4-1.0)\end{array}$ & $\begin{array}{c}\text { Day 7: } 1.9 \\
(0.7-5.5)\end{array}$ & & \\
\hline $\begin{array}{l}\text { Mechanical } \\
\text { ventilation }\end{array}$ & $11(0.5 \%)$ & $21(0.9 \%)$ & 0 & 0 & $\begin{array}{c}1(1.8 \% \\
\text { invasive } \\
\text { mechanical } \\
\text { ventilation) }\end{array}$ & $\begin{array}{c}1 \text { ( } 2 \% \text { non-invasive } \\
\text { mechanical ventilation) } \\
5 \text { ( } 10 \% \text {, intubated an } \\
\text { ventilatedmechanically) }\end{array}$ \\
\hline
\end{tabular}

Articles included have different endpoints as well. The first study by Tardif et al. ${ }^{3}$ has primary endpoints of composite of death or hospital admission. The secondary endpoints consisted of the components of the composite primary endpoints, and the need of mechanical ventilation. Adverse events such a pneumonia were also collected. This study found that the primary endpoints were met in 104 (4.7\%) of 2235 patients in the colchicine group, as compared with 131 (5.8\%) of 2253 patients in the placebo group. The rate of hospital admission was found to be 110 (4.9\%) of 2235 patients in the colchicine group and $138(6.1 \%)$ of 2253 patients in the placebo group (OR 0.79, 95\% CI 0.611.03; $\mathrm{p}=0.078$ ). Among the patients, ORs were 0.75 (95\% CI 0.57-0.99) for hospital admission and 0.56 (0.19-1.66) for death.
The secondary endpoints were met in 10 $(0.5 \%)$ of 2075 patients in the colchicine group, as compared with $20(1.0 \%)$ of 2084 patients in the placebo group. The percentage of adverse events was $24.2 \%$ in the colchicine group and $15.5 \%$ in the placebo group.

The second study by Lopez et al. ${ }^{4}$ has primary endpoints of clinical parameters such as time of need for supplemental oxygen, time of hospitalization, need for admission and length of stay in the ICU, and death rate and causes of mortality. As secondary endpoints, the study assessed clinical and laboratory parameters such as CRP level, LDH and relation neutrophil to lymphocyte of peripheral blood samples from day 0 to day 7 , the number, type, and severity of adverse events, frequency of interruption of the study protocol due to adverse events, and 
frequency of QT interval above 450ms. It was stated that the median (IQR) time of the need of supplemental oxygen was 4.0 (2.0-6.0) days in the colchicine group and 6.5 (4.0-9.0) days in the placebo group ( $\mathrm{p}<0.001)$. Median (IQR) time for hospitalization was 7.0 (5.0-9.0) days in the colchicine group and 9.0 (7.0-12.0) days in the placebo group ( $\mathrm{p}=0.003)$. Two patients died, both in placebo group.

The third study by Deftereos et al. ${ }^{5}$ has primary endpoints of maximum high-sensitivity cardiac troponin level, time for CRP to reach more that 3 times the upper reference limit, and time to deterioration by 2 points based on the 7 -grade clinical status scale. Secondary endpoints were the percentage of participants requiring mechanical ventilation, all-cause mortality, and the number, type, severity, and seriousness of adverse events. It was stated that at the end of the study, the median (IQR) peak high-sensitivity cardiac troponin values were $0.0112(0.0043-0.0093) \mathrm{ng} / \mathrm{mL}$ in the control group and 0.008 (0.004-0.0135) $\mathrm{ng} / \mathrm{mL}$ in the colchicine group $(\mathrm{p}=0.34)$. Median (IQR) maximum CRP levels were 4.5 (1.4-8.9) $\mathrm{mg} / \mathrm{dL}$ vs. $3.1(0.8-9.8) \mathrm{mg} / \mathrm{dL}$ $(p=0.73)$, respectively. Primary end point rate was $14 \%$ in the control group and $1.8 \%$ in the colchicine group (OR 0.11, $95 \%$ CI, 0.01- 0.96, $\mathrm{p}=0.02$ ). Details of the each study result is presented in TABLE 4 below.

TABLE 4. Description of each the study result

\begin{tabular}{|c|c|c|c|}
\hline Title & Author & Location, Time & Study Design \\
\hline $\begin{array}{l}\text { Colchicine for } \\
\text { community- } \\
\text { treated patients } \\
\text { with COVID-19 } \\
\text { (COLCORONA): } \\
\text { a phase 3, } \\
\text { randomised, } \\
\text { double-blinded, } \\
\text { adaptive, placebo- } \\
\text { controlled, } \\
\text { multicentre trial }\end{array}$ & Tardif et $a .^{3}$ & $\begin{array}{l}\text { Brazil, Canada, } \\
\text { Greece, South } \\
\text { Africa, Spain, } \\
\text { and USA; } 2020\end{array}$ & Multicentre trial \\
\hline
\end{tabular}

\begin{tabular}{|c|c|c|c|c|}
\hline $\begin{array}{l}\text { Beneficial effects } \\
\text { of colchicine } \\
\text { for moderate to } \\
\text { severe COVID- 19: } \\
\text { a randomised, } \\
\text { double-blinded, } \\
\text { placebo-controlled } \\
\text { clinical trial }\end{array}$ & Lopez et al. ${ }^{4}$ & Brazil, 2020 & $\begin{array}{l}\text { Randomized } \\
\text { Clinical Trial }\end{array}$ & $\begin{array}{l}\text { The median (IQR) time of the need of } \\
\text { supplemental oxygen was } 4.0(2.0-6.0) \\
\text { days in the colchicine group and } 6.5 \\
(4.0-9.0) \text { days in the placebo group } \\
(\mathrm{p}<0.001) \text {. Median (IQR) time for } \\
\text { hospitalization was } 7.0(5.0-9.0) \text { days in } \\
\text { the colchicine group and } 9.0(7.0-12.0) \\
\text { days in the placebo group ( } \mathrm{p}=0.003) \text {. } \\
\text { Two patients died, both in placebo } \\
\text { group. }\end{array}$ \\
\hline $\begin{array}{l}\text { Effect of colchicine } \\
\text { vs standard care } \\
\text { on cardiac and } \\
\text { inflammatory } \\
\text { biomarkers and } \\
\text { clinical outcomes } \\
\text { in patients } \\
\text { hospitalized with } \\
\text { covID-19 }\end{array}$ & Deftereos et al. ${ }^{5}$ & Grece, 2020 & $\begin{array}{l}\text { Randomized } \\
\text { Clinical Trial }\end{array}$ & $\begin{array}{l}\text { The median (IQR) peak high- sensitivity } \\
\text { cardiac troponin values were } 0.0112 \\
(0.0043-0.0093) \text { ng/mL in the control } \\
\text { group and } 0.008(0.004-0.0135) \mathrm{ng} / \\
\text { mL in the colchicine group }(\mathrm{p}=0.34) \text {. } \\
\text { Median (IQR) maximum CRP levels } \\
\text { were } 4.5(1.4-8.9) \mathrm{mg} / \mathrm{dL} \text { vs. } 3.1(0.8-9.8) \\
\mathrm{mg} / \mathrm{dL}(\mathrm{p}=0.73) \text {, respectively. Primary } \\
\text { end point rate was } 14 \% \text { in the control } \\
\text { group and } 1.8 \% \text { in the colchicine group } \\
\text { (OR } 0.11,95 \% \mathrm{CI}, 0.01-0.96, \mathrm{p}=0.02) \text {. }\end{array}$ \\
\hline
\end{tabular}


There were no serious adverse events that should be taken into account. In fact, according to one study, the number of patients with any serious adverse event (such as death of pneumonia) was smaller in the colchicine group than in the control group. In the study by Tardif et $a l .{ }^{3}$ serious adverse events were reported in 108 (4.9\%) of 2195 patients in the colchicine group and 139 (6.3\%) of 2217 patients in the placebo group $(\mathrm{p}=0.051)$, pneumonia was found in 63 (2.9\%) of 2195 patients in the colchicine group and 92 (4.1\%) of 2217 patients in the placebo group $(\mathrm{p}=0.021)$. This might reflect the reduction of inflammation in this disease due to colchicine. But it should be highlighted that in the colchicine group, the occurrence of diarrhea is consistently higher, as shown in TABLE 5. It was reported that in all studies, diarrhea was found more often in the colchicine group compared to the control group.

Colchicine causes diarrhea by affecting the mechanism that regulates water and electrolyte transport, the $\mathrm{Na}^{+} / \mathrm{K}^{+}$exchange pump. The energy that supports this exchange pump is provided by the ATPase mediated breakdown of ATP. ATPase may be inhibited by several drugs, including colchicine. Another mechanism which colchicine can cause diarrhea is by mucosal damage bowel. In the small intestine, mucosal damage causes diarrhea and fat malaborpsion. ${ }^{6}$

It should be noted that gastrointestinal problems have been reported in standard colchicine use for gout. They are the most common adverse effects in colchicine and often the first signs of toxicity that may indicate the dose needs to be reduces or stopped completely.

TABLE 5. Adverse effects (diarrhea)

\begin{tabular}{|c|c|c|c|}
\hline Study & Colchicine & Control & $\mathrm{p}$ \\
\hline Tardif et $a .^{3}$ & $300(13.7 \%)$ & $161(7.3 \%)$ & 0.0001 \\
\hline Lopez et al. ${ }^{4}$ & $6(17 \%)$ & $2(6 \%)$ & 0.26 \\
\hline Deftereos et al. ${ }^{5}$ & 25 (45.5\%) & $9(18 \%)$ & 0.003 \\
\hline
\end{tabular}

\section{DISCUSSION}

The addition of colchicine to standard treatment can be beneficial in treating COVID-19. All studies included showed that colchicine is a safe and welltolerated drug which has significantly improved time to clinical deterioration compared to the control group that did not receive colchicine. The drug was given early in the course of disease.

Colchicine reduced the length of hospitalization and the need for supplemental oxygen therapy. One of the included studies on community-treated patients, COLCORONA, mentioned that in outpatient settings, colchicine can be used to prevent hospitalization and even death.

Myocardial injury is a concern in
SARS-CoV-2 infection. The cardiovascular system is highly affected by the virus as the result of inflammation, endothelial activation, and microvascular thrombosis. ${ }^{7}$ In the GRECCO-19, there was no significant difference in hs cTn or CRP levels between the colchicine and the placebo group. Therefore, it ca not be concluded that colchicine has a cardioprotective effect in COVID-19 patients.

SARS-CoV-2 has been shown to activate the NLRP3 inflammasome. Activation of this inflammasome in lung tissues results in the activation of several ILs, which then triggers an inflammatory cascade. Elevation of ILs (such as IL-1 $\beta$ and IL-6) are associated with adverse clinical outcomes in COVID-19. The production of IL-1 $\beta$ drives 
the synthesis of IL-6, a cytokine that give rise to CRP and has been marked as a major proinflammatory agent in the COVID-19 cytokine storm. ${ }^{8}$ Which brings us to how colchicine can improve the clinical outcome and reduce death in COVID-19. There are several underlying mechanisms that might explain why the addition of colchicine into the COVID-19 management can be beneficial. First, colchicine as an anti-inflammatory drug reduces the lung inflammation in COVID-19. It was reported that the virus plays a role in neutrophil extracellular traps and the activation of NLRP3 inflammasome, causing a pathological cascade of acute lung injury and/or acute respiratory distress syndrome. Colchicine helps in the inhibition of inflammasome, reducing neutrophil migration, and activation or preventing endothelial damage. Although it is not fully clarified, it has been suggested that colchicine inhibits inflammasome in two ways: by inhibiting $\mathrm{P} 2 \mathrm{x} 7$ receptor activation and ASC polymerization, and also by suppressing mitochondrial transport and subsequent approximation of ASC to NLRP3. Second, colchicine interferes with the interaction of neutrophil and endothelial cells. It inhibits the expression of E-selectin on endothelial cells and prevents neutrophil adhesion. At higher concentration, colchicine promotes shedding of L-selectin from neutrophils and prevents further recruitment. In addition, colchicine might bind to the ends of microtubules, thus preventing the elongation of the microtubule polymer. Through the inhibition of microtubule polymerization, colchicine has been reported to be beneficial in inhibiting the replication of viruses. ${ }^{9}$ Based on these reasons, colchicine is believed to reduce the inflammation in COVID-19 and alter the severity and mortality of the disease.

\section{CONCLUSION}

Colchicine is a drug that can improve the clinical outcome of CRP levels, the number of patients that need mechanical ventilation, and death rate in COVID-19 patients. The addition of colchicine to standard treatment could be considered to help prevent clinical deterioration and death. Colchicine can also help reduce the number of adverse effects in COVID-19 patients except for gastrointestinal adverse effects, especially diarrhea, which is consistently more common in the patients with colchicine administration.

\section{ACKNOWLEDGEMENT}

I would like to thank who have supported to finish of this manuscript.

\section{REFERENCES}

1. Petersen E, Koopmans M, Go U, Hamer DH, Petrosillo N, Castelli F, et al. Comparing sars-cov-2 with sarscov and influenza pandemics. Lancet Infect Dis 2020; 20(9):E238-E44. https://doi.org/10.1016/S14733099(20)30484-9

2. Montealegre-Gómez G, Garavito E, Gómez-López A, Rojas-Villarraga A, Parra-Medina R. Colchicine: A potential therapeutic tool against COVID-19. Experience of 5 patients. Reumatol Clín 2021; 17(7):371-5. h t tps://doi.org/10.1016/j . reuma.2020.05.001

3. Tardif JC, Bouabdallaoui N, L'Allier PL, Gaudet D, Shah B, Pillinger $\mathrm{MH}$, et al. Colchicine for community-treated patients with COVID-10 (COLCORONA): a phase 3, randomised, double blinded, adaptive, placebo-controlled, multicentre trial. Lancet Respir Med 2021; 9(8):P924-32.

https://doi.org/10.1016/S22132600(21)00222-8

4. Lopez ME, Leticia PB, Giannini MC, Amaral NB, Menezes PI, Dib SM, et al. Beneficial effects of colchicine 
for treatment for moderate severe COVID-19: a randomised, double blinded, placebo-controlled clinical trial. RMD Open 2001; 7(1):7e001455. h t tps://d o i.org/10.1136/ rmdopen-2020-001455

5. Deftereos SG, Giannopoulos G, Vrachatis DA, Siasos GD, Giotaki SG, Gargalianos P, et al. Effect of Colchicinevsstandard care on cardiac and inflammatory biomarkers and clinical outcomesin patients hospitalized withcoronavirus disease 2019: The GRECCO-19 randomized clinical trial. JAMA Netw Open 2020; 3(6):e2013136.

h t t p s://d oi.org/10.1001/ jamanetworkopen.2020.13136

6. Satis H, Armagan B, Bodakci E, Atas $\mathrm{N}$, Sari A, Bilge NSY, et al. Colchicine intolerance in FMF patients and primary obstacles for optimal dosing. Turk J Med Sci 2020; 50(5):1337-43. https://doi.org/10.3906/sag-2001-261
7. Giustino G, Pinney SP, Lala A, Reddy VY, Johnston-Cox HA, Mechanick JI, et al. Coronavirus and cardiovascular disease, myocardial injury, and arrhythmia: JAAC Focus seminar. J Am Coll Cardiol 2020; 76(17):2011-23. h t t p s://d oi .org/10.1016/j . jacc.2020.08.059

8. López-Reyes A, Martinez-Armenta C, Espinosa-Velázquez R, VázquezCárdenas P, Cruz-Ramos M, Palacios-Gonzalez B, et al. NLRP3 inflammasome: the stormy link between obesity and COVID-19. Front Immunol 2020; 11:570251.

h t t p s://d o i.org/10.3389/ fimmu.2020.570251

9. Vitiello A, Ferrara F. Cochicine and SARS-CoV-2: management of The Hyperinflammatory state. Respir Med 2021; 178:106322.

ht tps://doi.org/10.1016/j . rmed.2021.106322 